\title{
Blue carbon in human-dominated estuarine and shallow coastal systems
}

\author{
Tomohiro Kuwae, Jota Kanda, Atsushi Kubo, Fumiyuki Nakajima, \\ Hiroshi Ogawa, Akio Sohma, Masahiro Suzumura
}

Received: 9 May 2015/Revised: 22 October 2015/Accepted: 22 October 2015/Published online: 3 November 2015

\begin{abstract}
Estuarine and shallow coastal systems (ESCS) are recognized as not only significant organic carbon reservoirs but also emitters of $\mathrm{CO}_{2}$ to the atmosphere through air-sea $\mathrm{CO}_{2}$ gas exchange, thus posing a dilemma on ESCS's role in climate change mitigation measures. However, some studies have shown that coastal waters take up atmospheric $\mathrm{CO}_{2}\left(\mathrm{C}_{\mathrm{atm}}\right)$, although the magnitude and determinants remain unclear. $\mathrm{We}$ argue that the phenomenon of net uptake of $\mathrm{C}_{\mathrm{atm}}$ by ESCS is not unusual under a given set of terrestrial inputs and geophysical conditions. We assessed the key properties of systems that show the net $\mathrm{C}_{\mathrm{atm}}$ uptake and found that they are often characteristic of human-dominated systems: (1) input of high terrestrial nutrients, (2) input of treated wastewater in which labile carbon is highly removed, and (3) presence of hypoxia. We propose that humandominated ESCS are worthy of investigation as a contributor to climate change mitigation.
\end{abstract}

Keywords Carbon cycles - Carbon sequestration Climate change $\cdot \mathrm{CO}_{2}$ fluxes $\cdot$ Urban ecology

\section{INTRODUCTION}

Quantifying carbon stocks, identifying and locating atmospheric $\mathrm{CO}_{2}\left(\mathrm{C}_{\mathrm{atm}}\right)$ sinks and sources, and understanding their drivers are important for climate change mitigation. Carbon transported from land and taken up from the atmosphere is stored within the ocean in various forms of organic and inorganic matter (IPCC 2013). In particular, coastal ecosystems are recognized as significant carbon reservoirs because of their high carbon burial rates and long-term sequestration of organic carbon (McLeod et al. 2011; Fourqurean et al. 2012; Duarte et al. 2013). So-called "blue carbon," termed by UNEP in 2009, is the carbon captured by marine living organisms (Nellemann et al. 2009). Estimates of stored blue carbon in a variety of shallow coastal ecosystems such as mangrove forests, salt marshes, seagrass meadows, and intertidal flats are ongoing (e.g., Chmura et al. 2003; Donato et al. 2011; Breithaupt et al. 2012; Fourqurean et al. 2012; Duarte et al. 2013; Miyajima et al. 2015). The organic carbon stored in shallow coastal sediment and within organisms is critical as a source of $\mathrm{CO}_{2}$ if significantly disturbed and oxidized by anthropogenic impacts, such as physical destruction and deterioration of water and sediment quality (McLeod et al. 2011; Fourqurean et al. 2012).

Despite growing understanding of the significance of blue carbon, there have been few syntheses of the efficacy of estuarine and shallow coastal systems (ESCS) as a means of climate change mitigation (Nellemann et al. 2009; McLeod et al. 2011; Duarte et al. 2013). Prediction is challenging because the dynamics of such waters are particularly complex; the presence of intertwined interfaces (air-water, water-sediment, air-sediment, and freshwatersaltwater) is associated with diverse biogeochemical cycles and biota as well as high exchange rates between interfaces. Nevertheless, there are some studies dealing with the stocks and fluxes of both organic and inorganic carbon in ESCS (Maher and Eyre 2012; Obrador and Pretus 2012; Tokoro et al. 2014) and the estimates are largely unconstrained (Cai 2011; Chen et al. 2013; Laruelle et al. 2013; Regnier et al. 2013).

A controversial point, less debated but still critical from the standpoint of blue carbon climate change mitigation, is that ESCS are generally recognized to be net emitters of $\mathrm{CO}_{2}$ to the atmosphere through air-sea $\mathrm{CO}_{2}$ gas exchange (e.g., Borges et al. 2005; Cai 2011; Chen et al. 2013; Laruelle et al. 2013; Regnier et al. 2013); although some 
studies have shown $\mathrm{C}_{\text {atm }}$ uptake (e.g., Kone et al. 2009). Hence, their role in climate change mitigation is paradoxical: ESCS indeed sequester carbon derived from the atmosphere yet they also emit $\mathrm{CO}_{2}$ to the atmosphere. Further, due to the geographical location of ESCS and the socio-economic history of use, the carbon fluxes of ESCS have long been altered by human activities (Bauer et al. 2013; Regnier et al. 2013). In particular, because wastewater treatment has a major impact on human-dominated coastal areas (McIntyre et al. 2000), we hypothesize that wastewater treatment affects $C_{a t m}$ exchange and benthic carbon storage.

Here, we discuss carbon stocks and fluxes related to climate change mitigation in ESCS. We targeted systems with a salinity of $1-33$, the rationale being the definition of estuaries as areas affected by both freshwater and saltwater. Therefore, we excluded continental shelves. By conceptualizing recent findings, we argue that the phenomenon of net uptake of $\mathrm{C}_{\mathrm{atm}}$ by ESCS is not unusual. We summarize the key factors that determine whether ESCS exhibit net uptake. Further, we argue that the relevance of anthropogenic impacts to air-sea $\mathrm{CO}_{2}$ fluxes and carbon burial in ESCS will become increasingly important to the study of human system-ecosystem interactions. Also, we suggest the need for further investigation of several overlooked coastal processes that potentially contribute to carbon sequestration from the atmosphere.

\section{DILEMMA OF BLUE CARBON IN CLIMATE CHANGE MITIGATION MEASURES}

Here, we discuss the dilemma of ESCS functioning related to climate change mitigation; both positive as a carbon reservoir and negative as a net emitter of $\mathrm{CO}_{2}$ to the atmosphere. However, we note that functioning as both a carbon reservoir and a net emitters of $\mathrm{CO}_{2}$ to the atmosphere is scientifically compatible (not paradoxical), as carbon flow in such ecosystems includes carbon transported from land, which is partly stored within ESCS, partly mineralized and outgassed, with the rest outflowed to the open ocean.

Recently, ESCS have been identified as areas of substantial blue carbon storage, particularly in the sediment (Nellemann et al. 2009; McLeod et al. 2011; Fourqurean et al. 2012; Duarte et al. 2013). Of the biogeochemical factors that influence carbon sequestration in sediments (e.g., Canfield 1994; Hartnett et al. 1998; Zonneveld et al. 2010; Koho et al. 2013), large amounts of allochthonous and autochthonous organic matter (Kennedy et al. 2010), mineral particles from rivers, and the mixing and settling (flocculation) of these materials may be responsible for high burial rates of carbon in ESCS (Sholkovitz 1976). As sediments vertically accrete, carbon burial occurs continuously unless significant, long-term elevation changes occur (e.g., sediment loss due to erosion and subsidence). The carbon that accumulates in sediments mineralizes slowly in subsurface layers where anoxic conditions exist and can be isolated from the earth's atmosphere for millennia (Chambers et al. 2001).

Shallow, vegetated coastal waters have the highest carbon burial rates in the ocean (average: $138-226 \mathrm{~g} \mathrm{C} \mathrm{m}^{-2}$ year $^{-1}$, range: $18-1713 \mathrm{~g} \mathrm{C} \mathrm{m}^{-2}$ year $\left.^{-1}\right)$, at least three orders of magnitude higher than in open ocean sediments $(0.018 \mathrm{~g} \mathrm{C}$ $\mathrm{m}^{-2}$ year $^{-1}$ ) (Nellemann et al. 2009; McLeod et al. 2011). The difference is not fully explained by the difference in net ecosystem production between shallow vegetated coastal waters (1044-2784 $\mathrm{g} \mathrm{C} \mathrm{m}^{-2}$ year $^{-1}$ ) and the open ocean (120 $\mathrm{g} \mathrm{C} \mathrm{m}^{-2}$ year $^{-1}$ ) (Gattuso et al. 1998). In shallow vegetated systems, restriction of water movement by vegetation stimulates trapping of particulate organic matter (POM) and carbon burial (Hendriks et al. 2007; Kennedy et al. 2010).

However, as noted, ESCS have been regarded as emitters of $\mathrm{CO}_{2}$, a consequence of the input of terrestrial carbon and its subsequent mineralization and respiration. Regnier et al. (2013) reported that the land-ocean aquatic continuum (comprised of freshwaters, estuaries, and continental shelves) is both a net emitter of $\mathrm{CO}_{2}\left(0.35 \mathrm{PgC}_{\mathrm{Cear}}{ }^{-1}\right)$ and a net carbon storage $\left(0.55 \pm 0.28 \mathrm{Pg} \mathrm{C}\right.$ year $\left.^{-1}\right)$. Such an apparent contradiction is the basis of the controversy about the role of ESCS in climate change mitigation measures.

\section{REQUIREMENTS FOR A LONG-TERM NET UPTAKE OF $\mathrm{C}_{\mathrm{ATM}}$}

Unlike sequestration in terrestrial ecosystems, aquatic carbon burial is not directly linked with the removal of $\mathrm{C}_{\mathrm{atm}}$, because the water column, within which complex inorganic and organic biogeochemical processes occur, separates the atmosphere from benthic systems. Only when the partial pressure of $\mathrm{CO}_{2}\left(\mathrm{pCO}_{2}\right)$ of the water is lower than that of the atmosphere at the air-water interface will a system absorb $\mathrm{C}_{\mathrm{atm}}$ (Wanninkhof 1992). Given that fluctuations of atmospheric $\mathrm{pCO}_{2}$ levels are small compared with fluctuations of surface water $\mathrm{pCO}_{2}$, factors that regulate surface water $\mathrm{pCO}_{2}$ are primarily responsible for determining the direction of the flux.

Lowering of surface water $\mathrm{pCO}_{2}$ is facilitated if allochthonous carbon (inorganic and organic) inputs are low and there are mechanisms to consume $\mathrm{CO}_{2}$ and suppress $\mathrm{CO}_{2}$ production. However, river water generally has a high $\mathrm{pCO}_{2}$ (Raymond et al. 2013; Regnier et al. 2013); the $\mathrm{pCO}_{2}$ values of $95 \%$ of global inland waters are higher than atmospheric $\mathrm{pCO}_{2}$, the median $\mathrm{pCO}_{2}$ being $3100 \mu$ atm (Raymond et al. 2013). Thus, for ESCS surface waters to become 
undersaturated with respect to $\mathrm{pCO}_{2}$, some process within the system must decrease the $\mathrm{pCO}_{2}$ of the water. Such processes include a decrease of temperature and dissolved inorganic carbon (DIC) as well as an increase of total alkalinity (TA).

For a system to show a long-term net uptake of $\mathrm{C}_{\mathrm{atm}}$, there must be a net unidirectional carbon influx (pump) when fluxes are averaged over years (Fig. 1). Of the various types of relevant carbon fluxes, burial of organic carbon in sediments, production of refractory dissolved organic carbon (RDOC), and export of particulate organic carbon (POC) are particularly important for the pump. All three of these processes have geological turnover rates and contribute to the suppression of mineralization and the resultant return of $\mathrm{CO}_{2}$ to the atmosphere.

\section{MECHANISTIC HYPOTHESIS FOR LONG-TERM $C_{\text {ATM }}$ UPTAKE IN HUMAN-DOMINATED ESCS}

Human impacts on ESCS alter carbon cycling. One can expect that these impacts alter $\mathrm{C}_{\mathrm{atm}}$ exchanges and benthic carbon storage by increasing nutrient loading, wastewater treatment, and freshwater use (McIntyre et al. 2000). Below, by synthesizing mechanistic hypotheses and empirical evidence from previous studies (Table 1), we conceptualize that human impacts are closely related to the creation of $\mathrm{C}_{\mathrm{atm}}$ uptake. Our hypothesis is that discharges of high-nutrient but relatively low-carbon water generated by wastewater treatment, as well as an increase in freshwater discharges due to importation of freshwater and watershed alteration, are key to enhancing direct uptake of $\mathrm{C}_{\mathrm{atm}}$ in ESCS (Fig. 2). We acknowledge that our hypothesis should be quantitatively validated by numerical modeling.

\section{Wastewater treatment}

Wastewater treatment has a considerable impact on biogeochemical cycles in human-dominated ESCS (Grimm et al. 2008; Kaushal and Belt 2012; Kubo et al. 2015). We propose that wastewater treatment can contribute to the creation of the long-term net uptake of $\mathrm{C}_{\mathrm{atm}}$ in human-

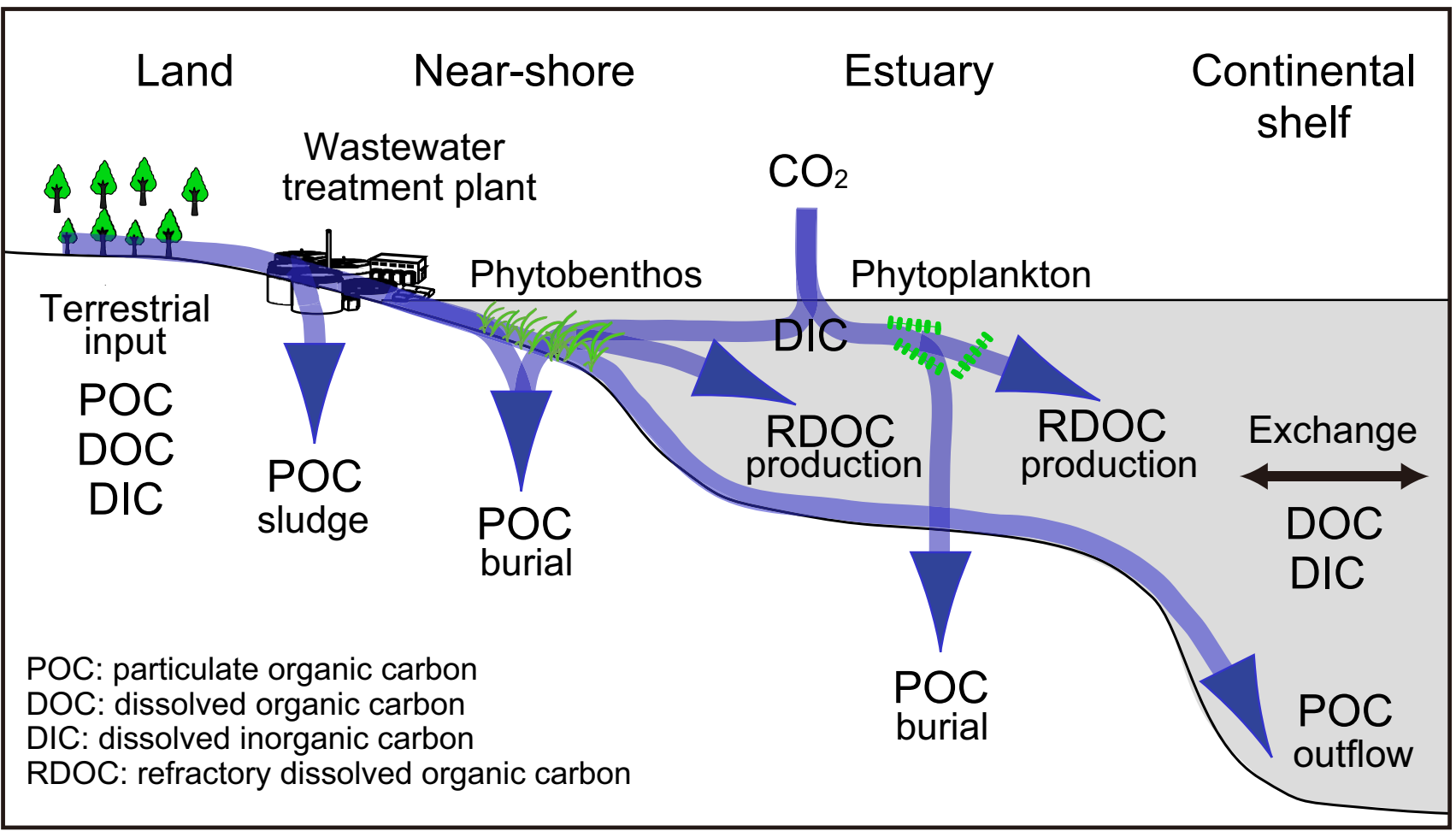

Fig. 1 Conceptualized carbon flows that contribute to a long-term net uptake of $\mathrm{C}_{\mathrm{atm}}$ in ESCS. The conceptual diagram is based on the assumption that a long-term net uptake (at least over years) of $\mathrm{C}_{\text {atm }}$ occurs only when there is a net unidirectional carbon flux (pump) that leads to a partial pressure of $\mathrm{CO}_{2}\left(\mathrm{pCO}_{2}\right)$ in water lower than the atmospheric $\mathrm{pCO}_{2}$. Lowering of $\mathrm{pCO}_{2}$ is enhanced by (1) primary production by phytoplankton and phytobenthos (submerged aquatic vegetation), (2) suppression of mineralization and release of $\mathrm{CO}_{2}$ by production of refractory dissolved organic matter (RDOC), (3) sedimentation and burial of particulate organic matter (POC), and (4) efflux of POC into the deep sea. Wastewater treatment plants can indirectly contribute to lowering of $\mathrm{pCO}_{2}$ in water by removal of POC (sludge) in terrestrial inputs; however, the plants can also be emitters of $\mathrm{CO}_{2}$ to the atmosphere due to water treatment (oxygenation of wastewater and mineralization of organic matter in open treatment basins) 
Table 1 Key processes and mechanisms relevant to air-sea $\mathrm{CO}_{2}$ fluxes and carbon burial in human-dominated ESCS

\begin{tabular}{|c|c|c|c|}
\hline Property & Driver & Consequence & $\begin{array}{l}\text { Relevance to } \\
\text { atmospheric } \mathrm{CO}_{2} \\
\text { uptake and carbon } \\
\text { burial }\end{array}$ \\
\hline $\begin{array}{l}\text { Large amount of } \\
\text { nutrient input }\end{array}$ & Nutrient input from land & Enhancement of high primary production & Low $\mathrm{pCO}_{2}$ in water \\
\hline $\begin{array}{l}\text { Relatively small } \\
\text { amount of labile } \\
\text { carbon input }\end{array}$ & $\begin{array}{l}\text { Wastewater treatment (removal } \\
\text { and mineralization of organic } \\
\text { carbon) }\end{array}$ & $\begin{array}{l}\text { Relatively low-carbon mass input to sea } \\
\text { Suppression of mineralization but less suppression of } \\
\text { primary production }\end{array}$ & Low $\mathrm{pCO}_{2}$ in water \\
\hline $\begin{array}{l}\text { Large amount of } \\
\text { freshwater } \\
\text { discharge }\end{array}$ & $\begin{array}{l}\text { Freshwater demand due to } \\
\text { population (importation of } \\
\text { water, watershed alteration) }\end{array}$ & $\begin{array}{l}\text { Enhancement of stratification } \\
\text { Suppression of upwelling of high-DIC-concentration bottom } \\
\text { waters due to stratification } \\
\text { Low turbidity in surface water due to suppression of } \\
\text { resuspension and upwelling of POC from bottom water, } \\
\text { enhancing light availability and photosynthesis }\end{array}$ & $\begin{array}{l}\text { Low } \mathrm{pCO}_{2} \text { in surface } \\
\text { water }\end{array}$ \\
\hline $\begin{array}{l}\text { Presence of oxygen } \\
\text { minimum zone } \\
(\text { OMZ) }\end{array}$ & $\begin{array}{l}\text { Stratification } \\
\text { High organic matter input }\end{array}$ & $\begin{array}{l}\text { Anoxia/hypoxia in both bottom water and surface sediments } \\
\text { Suppression of mineralization } \\
\text { Production of POC by anoxic/hypoxic polymerization }\end{array}$ & $\begin{array}{l}\text { Enhancement of carbon } \\
\text { burial }\end{array}$ \\
\hline $\begin{array}{l}\text { Shallow water } \\
\text { depth }\end{array}$ & Geological settings & Short degradation time during POC sinking in water column & $\begin{array}{l}\text { Enhancement of carbon } \\
\text { burial }\end{array}$ \\
\hline Turbidity & $\begin{array}{l}\text { Plankton blooming } \\
\text { Mineral particle input from } \\
\text { terrestrial }\end{array}$ & $\begin{array}{l}\text { Enhancement of primary production due to increase in } \\
\text { phytoplankton biomass, lowering } \mathrm{pCO}_{2} \\
\text { Suspended particles suppressing light availability and } \\
\text { photosynthesis, raising } \mathrm{pCO}_{2}\end{array}$ & $\begin{array}{l}\text { Variability of } \mathrm{pCO}_{2} \text { in } \\
\text { surface water }\end{array}$ \\
\hline Residence time & $\begin{array}{l}\text { Freshwater input } \\
\text { Water exchange at the boundary }\end{array}$ & $\begin{array}{l}\text { Influenced by the quantity and quality }\left(\mathrm{pCO}_{2} \text { and } \mathrm{POC}\right) \text { of } \\
\text { inflowing water }\end{array}$ & $\begin{array}{l}\text { Variability of } \mathrm{pCO}_{2} \text { in } \\
\text { surface water and } \\
\text { carbon burial }\end{array}$ \\
\hline
\end{tabular}

dominated ESCS for two reasons. First, current wastewater treatment, such as the conventional activated sludge method, removes carbon in the form of sludge and $\mathrm{CO}_{2}$ gas more efficiently than nutrients such as nitrogen and phosphorus (Sedlak 1991). Through these effluents, the balance of primary production and respiration in the ESCS is offset towards an excess of primary production and the resultant suppression of any $\mathrm{pCO}_{2}$ increase. Second, the effluent contains relatively refractory carbon, because labile organic matter has already been removed by treatment (Kubo et al. 2015). Therefore, respiration and mineralization rates of effluent are low, and subsequent $\mathrm{pCO}_{2}$ increases are suppressed.

\section{Freshwater use, stratification, and hypoxia}

Human populations rely on large amounts of freshwater, and watershed hydrologic alteration is often employed to meet demands (Grimm et al. 2008; Kaushal and Belt 2012). An increase of runoff and possibly the temperature by human use enhances stratification and water exchanges in ESCS, thereby indirectly but significantly affecting biogeochemical cycles in these systems.

Stratified water hinders upwelling of high-DIC bottom water and suppresses increases of DIC and $\mathrm{pCO}_{2}$ in the surface water and air-sea $\mathrm{CO}_{2}$ efflux. However, unlike the effect of stratification on DIC behavior, sinking of POM from the surface water is not hindered by stratification (Kone et al. 2009). Thus, POM, which is the potential source of DIC in surface waters, moves downward via sinking, independent of the degree of stratification (Fig. 2). In particular, because ESCS have shallow water columns, the time for settling of POM to the bottom is shorter (little POM is mineralized) than in the case of the open ocean, where most POM is mineralized before reaching the bottom. Also, stratification suppresses resuspension from bottom waters as well as upwelling of resuspended particles (turbidity). Therefore, transparency is enhanced, light is more available for photosynthesis, and the $\mathrm{pCO}_{2}$ of the surface water is lowered (Chen et al. 2008).

Stratification is seasonal in temperate and boreal regions, occurring mainly in summer. Such seasonality may, in turn, influence the dynamics of air-sea $\mathrm{CO}_{2}$ exchanges. During summer, stratification blocks upwelling of bottom waters containing high concentrations of DIC. During other seasons, in the absence of stratification, highDIC bottom water is mixed with surface water, the result being an increase of $\mathrm{pCO}_{2}$ in surface water and enhancement of the $\mathrm{CO}_{2}$ efflux into the atmosphere. However, lower temperatures during these times suppress the efflux 


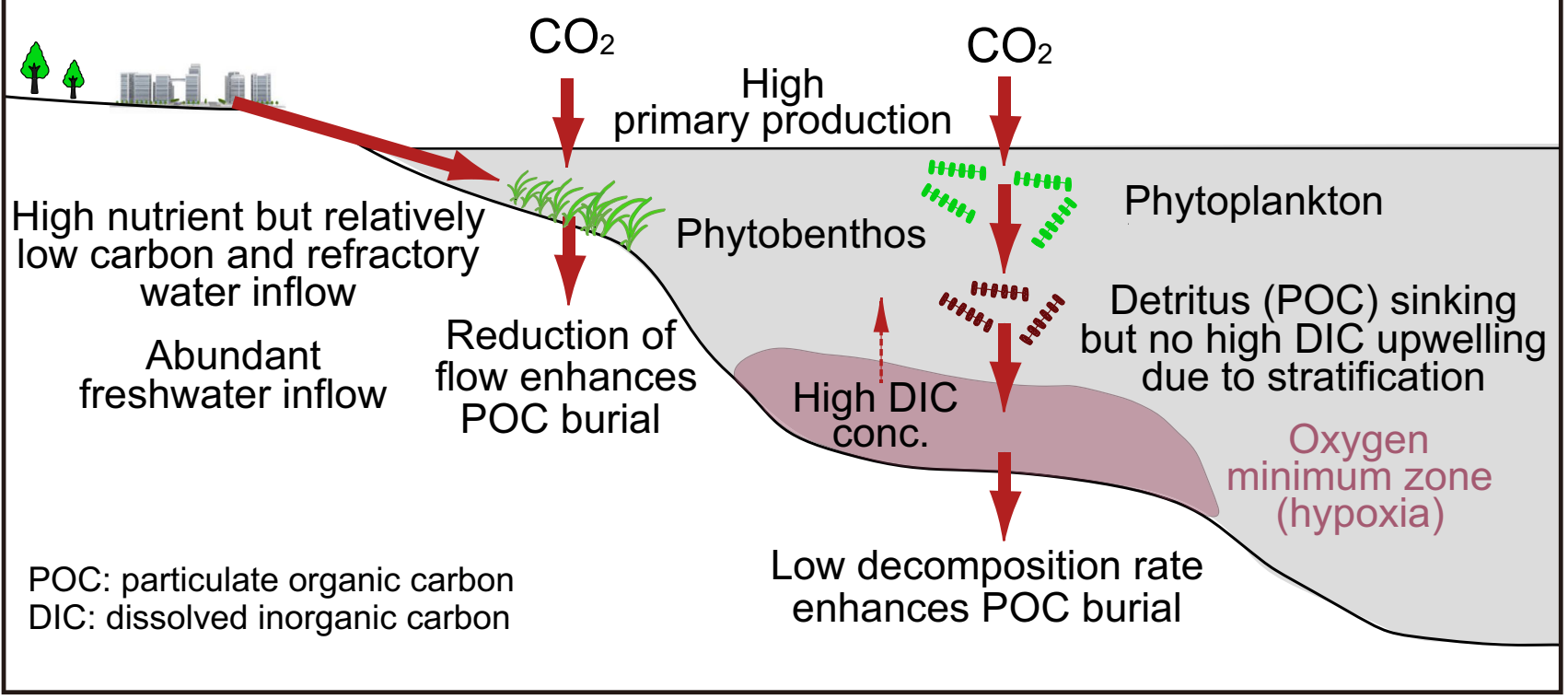

Fig. 2 Key processes and mechanisms that explain why human-dominated ESCS show net uptake of $\mathrm{C}_{\text {atm }}$ at least over years through air-sea $\mathrm{CO}_{2}$ gas exchange. For details, see Table 1

of $\mathrm{CO}_{2}$ because of the negative correlation between $\mathrm{CO}_{2}$ solubility and temperature.

Mineralization rates are acknowledged to be low under low-oxygen conditions (Hartnett et al. 1998; Koho et al. 2013), although the issue is contentious (Canfield 1994). Because lability related to redox potential is dependent on the nature of the organic matter (Zonneveld et al. 2010), we expect that less organic matter is mineralized in a narrower range of redox potential than in a broader range (e.g., having both negative and positive redox potential variations). Thus, the hypoxia or oxygen minimum zone (OMZ) that forms in a stratified water column can geochemically enhance carbon burial because redox ranges in the sediment will be narrower than without OMZ. Further, biological processes also mediate carbon burial in the OMZ. For example, Koho et al. (2013) reported that carbon burial is high in the OMZ because macrofaunal manipulation of organic carbon particles and bioturbation are less prevalent under hypoxic conditions. However, the OMZ also enhances production of potent greenhouse gases $\left(\mathrm{N}_{2} \mathrm{O}\right.$ and $\mathrm{CH}_{4}$ ), offsetting climate change mitigation.

Turbidity affects surface water $\mathrm{pCO}_{2}$ both positively and negatively. If the source of turbidity mainly consists of phytoplankton, primary production can be enhanced by an increase in phytoplankton biomass, leading to lowering of $\mathrm{pCO}_{2}$. In turn, if the source mainly consists of mineral particles, light availability and photosynthesis are suppressed, leading to raising of $\mathrm{pCO}_{2}$ (Chen et al. 2012). Also, residence time is a critical factor for determining both surface water $\mathrm{pCO}_{2}$ and carbon burial, affecting both positively and negatively because they are influenced by the quantity and quality $\left(\mathrm{pCO}_{2}\right.$ and $\left.\mathrm{POC}\right)$ of inflowing water (Gazeau et al. 2005).

\section{Field studies}

Here we show published data for ESCS influenced in key ways by anthropogenic impacts. Since estimated global average $\mathrm{CO}_{2}$ fluxes for small deltas, tidal systems, and lagoons, net emitters of $\mathrm{CO}_{2}$ to the atmosphere, have already been compiled elsewhere (Laruelle et al. 2013), we focused on previous field cases where ESCS showed $\mathrm{C}_{\mathrm{atm}}$ uptake (Table 2) using available databases (Google Scholar and Scopus). In most instances, we found that the ESCS showing $\mathrm{C}_{\mathrm{atm}}$ uptake were, variously, impacted by treated wastewater, stratified, or characterized by the presence of hypoxia. Inputs of wastewater, clearly related to land use impacted by anthropogenic activities (urban and farmland), led to high concentrations of nutrients and chlorophyll $a$, and high primary production rates in the ESCS. Positive relationships between net ecosystem production (metabolism) and $\mathrm{C}_{\mathrm{atm}}$ absorption have been shown (Maher and Eyre 2012; Tokoro et al. 2014). In shallow coastal ecosystems, we found that air-sea $\mathrm{CO}_{2}$ fluxes were negative (ESCS takes up $\mathrm{C}_{\mathrm{atm}}$ ) only where seagrass meadows were present, although there are reports showing undersaturated $\mathrm{pCO}_{2}$ [e.g., kelp beds (Delille et al. 2009) and coral reefs (Kayanne et al. 1995, 2005)]. The result may, in 


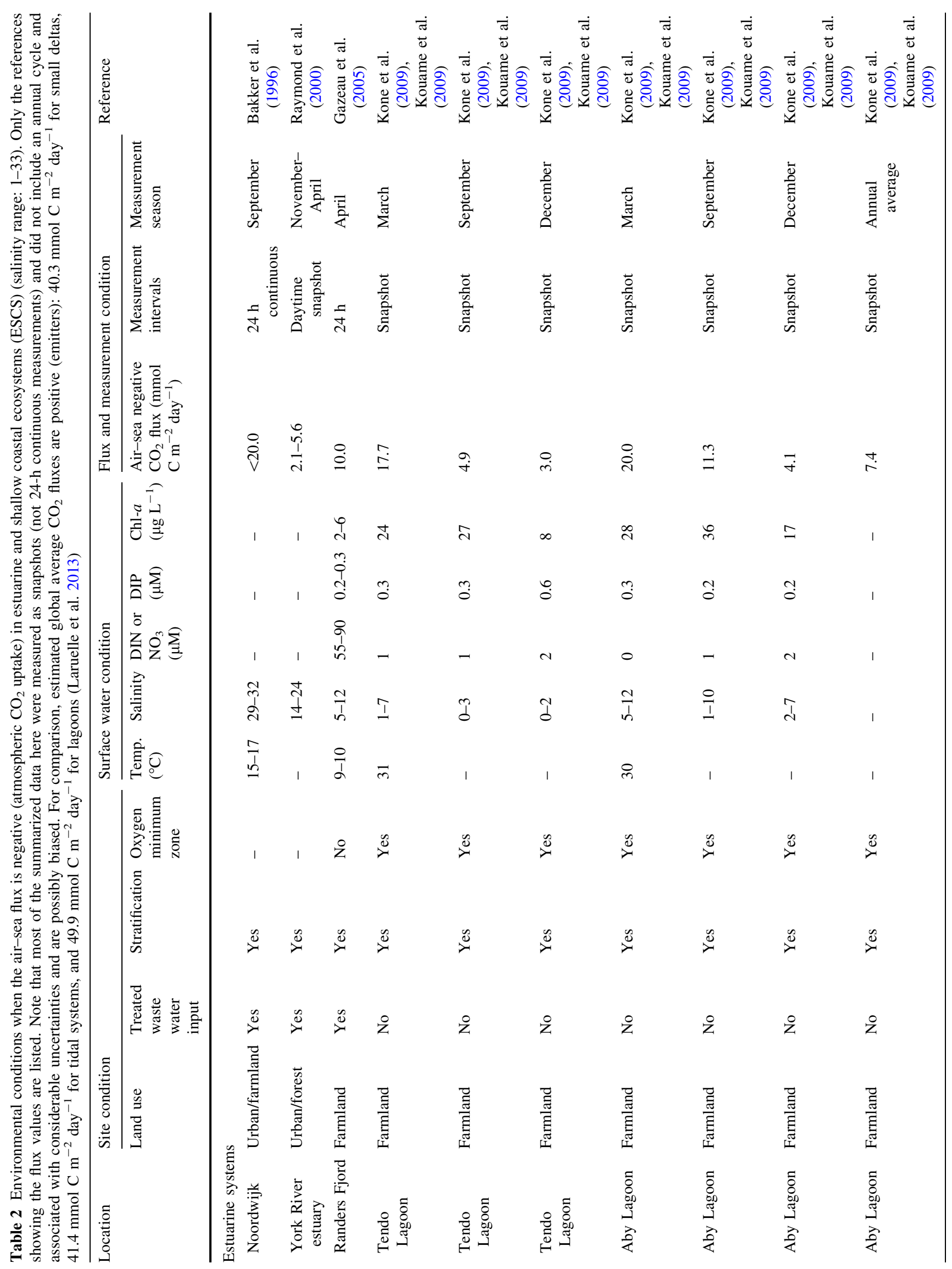

(C) The Author(s) 2015. This article is published with open access at Springerlink.com 


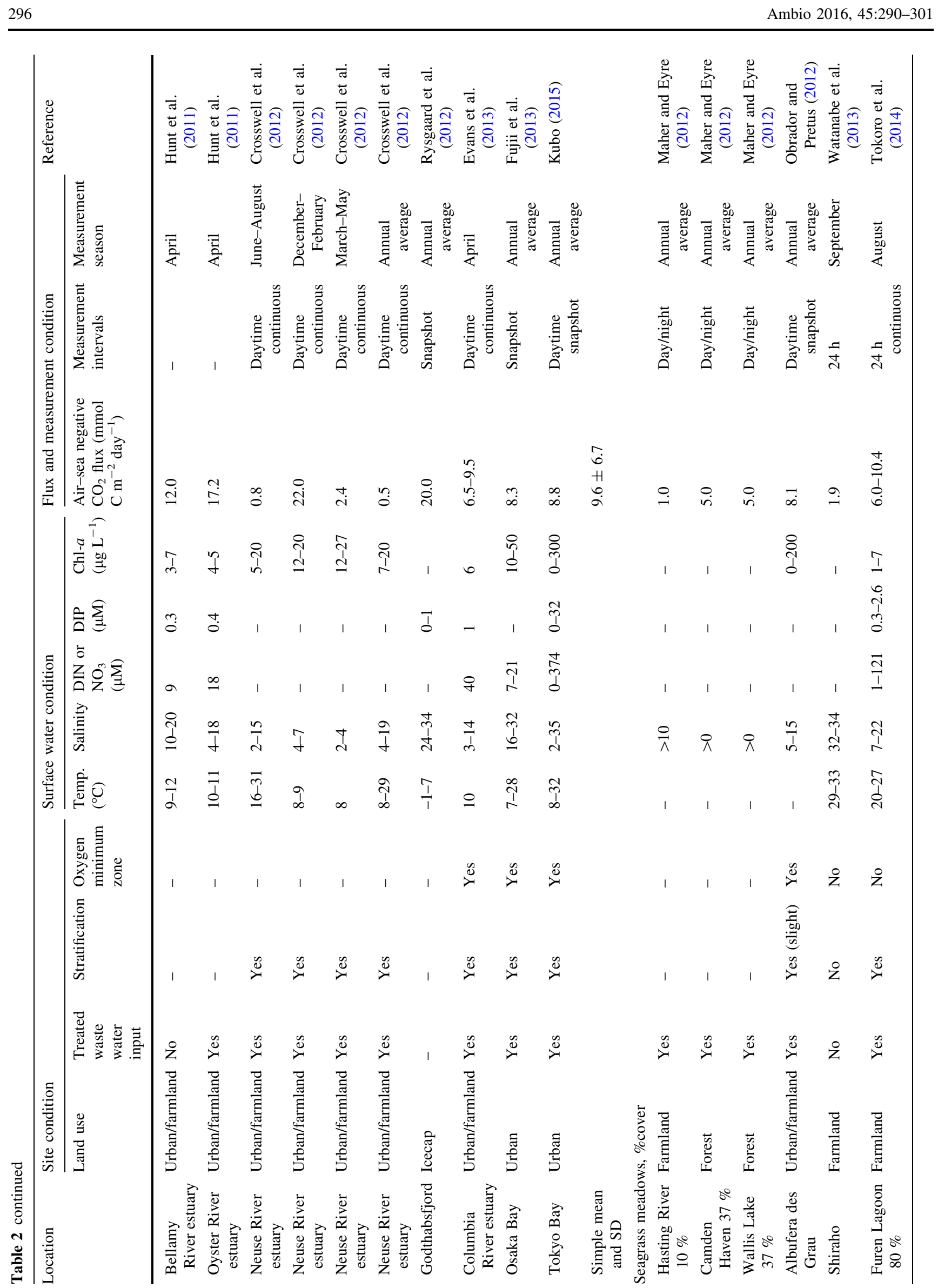

Springer

(C) The Authors) 2015. This article is published with open access at Springerlink.com

www.kva.se/en 


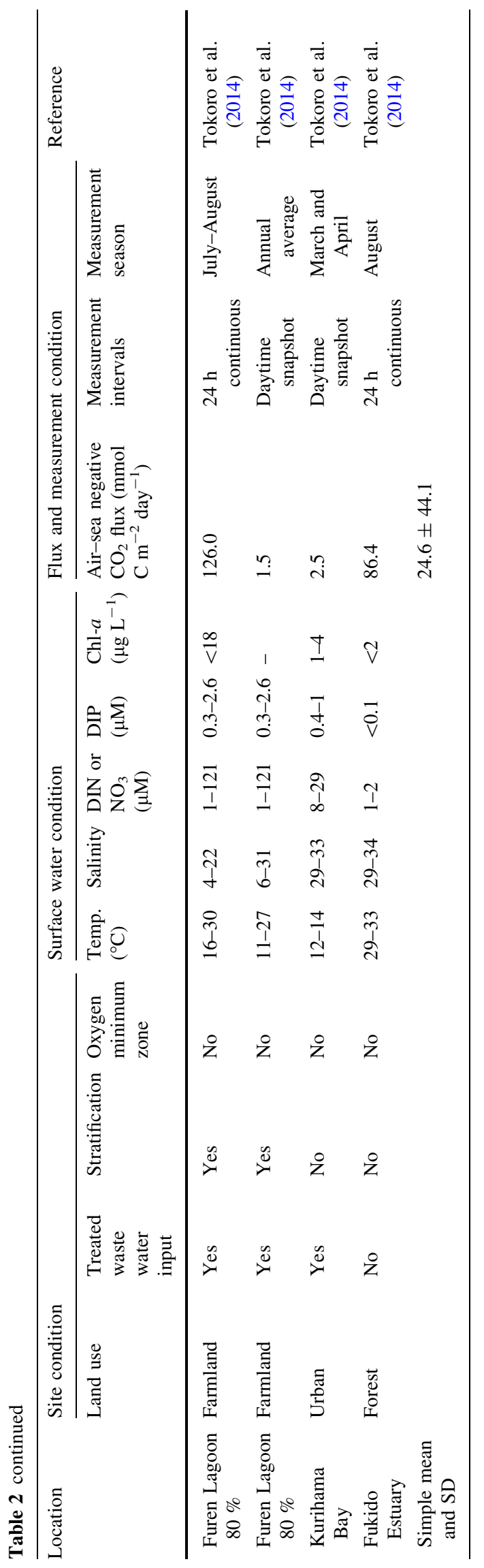

part, reflect that in this study, we focused on ecosystems where the salinity was $1-33$, which is uncommonly low for kelp beds and coral reefs. We found that the magnitude of the average $\mathrm{CO}_{2}$ influx was higher in seagrass meadows $\left(24.6 \pm 44.1 \mathrm{mmol} \mathrm{C} \mathrm{m}^{-2} \mathrm{day}^{-1}\right.$, mean $\left.\pm \mathrm{SD}\right)$ than in estuarine systems $\quad\left(9.6 \pm 6.7 \mathrm{mmol} \quad \mathrm{C} \quad \mathrm{m}^{-2}\right.$ day $^{-1}$, mean $\pm \mathrm{SD}$ ). In contrast, estimated global average $\mathrm{CO}_{2}$ fluxes were positive (effluxes) for small deltas $(40.3 \mathrm{mmol}$ $\mathrm{C} \mathrm{m}^{-2}$ day $^{-1}$ ), tidal systems (41.4 mmol $\mathrm{C} \mathrm{m}^{-2}$ day $^{-1}$ ), and lagoons (49.9 mmol C m${ }^{-2}$ day $^{-1}$ ) (Laruelle et al. 2013).

However, we note that most summarized data were measured as snapshots (not 24-h continuous measurements) and did not include an annual cycle. The implication is that these data and average fluxes are associated with considerable uncertainties and are possibly biased. In particular, diurnal $\mathrm{pCO}_{2}$ changes are significant in lowsalinity environments, where the carbonate buffer effect is weak, but few studies have documented the changes. Hence, we could not use statistical models to analyze the flux data and infer the drivers.

\section{UNEXPLORED BUT IMPORTANT PROCESSES}

Of the anticipated carbon fluxes that can contribute to removal of $\mathrm{C}_{\mathrm{atm}}$, an important pathway is related to RDOC (Ogawa et al. 2001; Jiao et al. 2014; Kubo et al. 2015). Of the riverine carbon flux to the global coastal ocean, the DOC flux (246 Tg C year ${ }^{-1}$ ) comprises $28 \%$ of the total carbon flux (869 $\mathrm{C} \mathrm{year}^{-1}$ ) (Cai 2011). Air-sea $\mathrm{CO}_{2}$ fluxes in ESCS can be affected by how much DOC is mineralized into $\mathrm{CO}_{2}$ by microbial and photochemical processes (Moran et al. 2000) and how much new RDOC is produced within the systems (Fig. 1). The new production of RDOC within these systems is a largely unexplored process. RDOC is reported to be derived from phytoplankton (Kragh and Søndergaard 2009), bacteria (Ogawa et al. 2001; Lønborg et al. 2009), phytobenthos (Wada et al. 2008), and corals (Tanaka et al. 2011a, b). As above, inputs of organic matter with rich nutrients and less labile organic carbon can lower water column $\mathrm{pCO}_{2}$ and enhance $\mathrm{C}_{\mathrm{atm}}$ uptake in ESCS; however, these conditions may decrease RDOC concentrations due to the priming effect (remobilization of RDOC by bacterial use of nutrients) (Taylor and Townsend 2010; Jiao et al. 2014). Thus, we note that the impact of interactions between DOC and nutrients on carbon sequestration is complex. Further, to evaluate the role of DOC in carbon sequestration, we need to quantify how much new DOC is synthesized from both allochthonous and autochthonous sources. However, identification and quantification of the source of new DOC remains technologically challenging because of the low 
concentration of DOC and the presence of salt, which interferes with quantification.

Carbon taken up by vegetation, such as seagrasses and seaweeds, and exported and sequestered in the deep sea, where it is mineralized and returned to the atmosphere as $\mathrm{CO}_{2}$ on a geological time-scale, is an important mechanism for $\mathrm{C}_{\mathrm{atm}}$ sequestration (Kennedy et al. 2010) (Fig. 1). The extent of burial or degradation of seagrass shoots and rhizomes is largely unknown, but the magnitude of the global export flux has been estimated to be $0.05-0.1 \mathrm{Pg} \mathrm{C}_{\text {year }}{ }^{-1}$ (McLeod et al. 2011). In addition, new production (or transformation by polymerization) of RPOC within ESCS (both in the water column and sediment) (Zonneveld et al. 2010 ) is a process that may contribute to $C_{a t m}$ sequestration. However, this process has yet to be investigated.

\section{FUTURE DIRECTIONS}

\section{Need for more air-sea $\mathrm{CO}_{2}$ flux data}

Compared to terrestrial and open ocean ecosystems, available data for $\mathrm{CO}_{2}$ gas exchanges and associated parameters in ESCS are scarce (Laruelle et al. 2013) and have yet to be included in the assessment report of the IPCC. A suite of key data for carbon cycling, such as airwater $\mathrm{CO}_{2}$ fluxes, carbonate chemistry, and organic carbon dynamics in coastal areas, are necessary to ascertain whether the various ESCS show net uptake or emission of $\mathrm{CO}_{2}$ (Maher and Eyre 2012; Obrador and Pretus 2012; Tokoro et al. 2014). Further, long-term air-sea $\mathrm{CO}_{2}$ flux data are needed to assess the variability and uncertainty of the flux associated with timescales, which is important for consideration of gas exchange-based accounting of $\mathrm{CO}_{2}$ as well as possible future anthropogenic impacts on air-sea $\mathrm{CO}_{2}$ exchange. Indeed, a numerical simulation has predicted that the trend of air-sea $\mathrm{CO}_{2}$ exchange is towards an increasing net uptake in coastal waters (including continental shelves) due to rising atmospheric $\mathrm{pCO}_{2}$ and increasing inorganic nutrient loads (Andersson and Mackenzie 2004).

\section{Re-evaluation of sequestered carbon}

Most studies related to blue carbon in ESCS and the importance of conserving these systems hinge on the assumption that if such ecosystems were lost, all the stored carbon would be mineralized and released into the atmosphere as $\mathrm{CO}_{2}$ (e.g., McLeod et al. 2011; Fourqurean et al. 2012). However, such an assumption is a worst-case scenario and further investigation is required (Pendleton et al. 2012; Macreadie et al. 2014). Finally, there is the argument over whether or not buried carbon derived from outside
ESCS should be included with the autochthonous as carbon sequestered by ESCS. Some reports have estimated the separate proportion of autochthonous and allochthonous carbon contributions (Middelburg et al. 1997; Kennedy et al. 2010; Dubois et al. 2012; Watanabe and Kuwae 2015). The same argument would be true for whether or not exported POC should be included as carbon sequestered by ESCS.

\section{Mitigation by management of wastewater treatment}

Carbon removal in wastewater treatment means that a significant part of the carbon removed is released as $\mathrm{CO}_{2}$ from the treatment plant instead of from the ESCS water surface. That is, if we view the process of $\mathrm{CO}_{2}$ gas exchange as part of an integrated system involving the entire coasts (i.e., the area including both the ESCS and the land where treatment plants are built), then $\mathrm{C}_{\mathrm{atm}}$ uptake by the ESCS may be canceled out by $\mathrm{CO}_{2}$ emissions from the treatment plants. However, by appropriate management of the treatment process, we can benefit from both reduction of carbon emissions and atmospheric carbon uptake. For example, generated sludge can be utilized as a biofuel and generated $\mathrm{CO}_{2}$ for in situ capture and storage, and we can choose anaerobic treatments (e.g., methane fermentation) to use the emitted gas as a biofuel (Parkin and Owen 1986). In addition, we can manage the efficiency of carbon and nutrient removals as well as the quality of the treated water by selecting alternative treatment methods (e.g., coagulating sedimentation method, anaerobic-anoxic-oxic method). These human system-ecosystem interactions are complex, and biogeochemical modeling and numerical simulations appear necessary to inform optimal management of ESCS-based measures for mitigation and adaptation to climate change.

\section{CONCLUSION}

ESCS are recognized as not only significant carbon reservoirs but also emitters of $\mathrm{CO}_{2}$ to the atmosphere through air-sea $\mathrm{CO}_{2}$ gas exchange, posing the dilemma of how ESCS functions relate to climate change mitigation measures. By synthesizing mechanistic hypotheses and empirical evidence from previous studies, we argue that the capability of ESCS to function as direct net uptake of $\mathrm{C}_{\text {atm }}$ over years is not exceptional and $\mathrm{CO}_{2}$ uptake is closely related to environmental conditions typical of humandominated systems. Thus, our study offers a new perspective on the potential of human-dominated ESCS as a contributor to climate change mitigation, i.e., both carbon reservoirs and direct net uptake of $\mathrm{C}_{\mathrm{atm}}$, in light of human systems-ecosystem interactions. In particular, investigation 
should be focused on vegetated ecosystems in ESCS, e.g., mangrove forests, salt marshes, and seagrass meadows as these ecosystems have high carbon burial rates and longterm carbon storage capability. Further, ecosystem conservation, restoration, and management appear more feasible to implement compared to other climate change mitigation options, such as ocean fertilization and geological carbon storage (Nellemann et al. 2009; Cusack et al. 2014). However, validating the potential of ESCS will require field studies to allow development of improved hydrographic-biogeochemical ESCS models.

Acknowledgments We thank T. Tokoro, K. Watanabe, N. Tsurushima, N. Yamada, Y. Nakagawa, and R. W. Elner for helpful comments. We also thank two anonymous referees for helpful comments on the manuscript. Part of this study was supported by a Canon Foundation grant to $\mathrm{T}$. K. and Grant-in-Aid for Challenging Exploratory Research (No. 24656316, 26630251) from the Japan Society for the Promotion of Science (JSPS) to T. K.

Open Access This article is distributed under the terms of the Creative Commons Attribution 4.0 International License (http:// creativecommons.org/licenses/by/4.0/), which permits unrestricted use, distribution, and reproduction in any medium, provided you give appropriate credit to the original author(s) and the source, provide a link to the Creative Commons license, and indicate if changes were made.

\section{REFERENCES}

Andersson, A.J., and F.T. Mackenzie. 2004. Shallow-water oceans: A source or sink of atmospheric $\mathrm{CO}_{2}$ ? Frontiers in Ecology and the Environment 2: 348-353.

Bakker, D.C., H.J. de Baar, and H.P. de Wilde. 1996. Dissolved carbon dioxide in Dutch coastal waters. Marine Chemistry 55: $247-263$.

Borges, A.V., B. Delille, and M. Frankignoulle. 2005. Budgeting sinks and sources of $\mathrm{CO}_{2}$ in the coastal ocean: Diversity of ecosystem counts. Geophysical Research Letters 32: L14601.

Breithaupt, J. L., J. M. Smoak, T. J. Smith, C. J. Sanders, and A. Hoare. 2012. Organic carbon burial rates in mangrove sediments: Strengthening the global budget. Global Biogeochemical Cycles 26: GB3011.

Cai, W.J. 2011. Estuarine and coastal ocean carbon paradox: $\mathrm{CO}_{2}$ sinks or sites of terrestrial carbon incineration? Annual Review of Marine Science 3: 123-145.

Canfield, D.E. 1994. Factors influencing organic carbon preservation in marine sediments. Chemical Geology 114: 315-329.

Chambers, J.Q., N. Higuchi, E.S. Tribuzy, and S.R. Trumbore. 2001. Carbon sinks for a century. Nature 410: 429.

Chen, C.T.A., W. Zhai, and M. Dai. 2008. Riverine input and air-sea $\mathrm{CO}_{2}$ exchanges near the Changjiang (Yangtze River) estuary: Status quo and implication on possible future changes in metabolic status. Continental Shelf Research 28: 1476-1482.

Chen, C.T.A., T.H. Huang, Y.H. Fu, Y. Bai, and X. He. 2012. Strong sources of $\mathrm{CO}_{2}$ in upper estuaries become sinks of $\mathrm{CO}_{2}$ in large river plumes. Current Opinion in Environmental Sustainability 4: $179-185$.

Chen, C.T.A., T.H. Huang, Y.C. Chen, Y. Bai, X. He, and Y. Kang. 2013. Air-sea exchange of $\mathrm{CO}_{2}$ in world's coastal seas. Biogeosciences 10: 6509-6544.
Chmura, G.L., S.C. Anisfeld, D.R. Cahoon, and J.C. Lynch. 2003. Global carbon sequestration in tidal, saline wetland soils. Global Biogeochemical Cycles 17: 1111.

Crosswell, J.R., M.S. Wetz, B. Hales, and H.W. Paerl. 2012. Airwater $\mathrm{CO}_{2}$ fluxes in the microtidal Neuse River Estuary, North Carolina. Journal of Geophysical Research 117: C8.

Cusack, D.F., J. Axsen, R. Shwom, L. Hartzell-Nichols, S. White, and K.R.M. Mackey. 2014. An interdisciplinary assessment of climate engineering strategies. Frontiers in Ecology and the Environment 12: 280-287.

Delille, B., A.V. Borges, and D. Delille. 2009. Influence of giant kelp beds (Macrocystis pyrifera) on diel cycles of $\mathrm{pCO}_{2}$ and DIC in the Sub-Antarctic coastal area. Estuarine, Coastal and Shelf Science 81: 114-122.

Donato, D.C., J.B. Kauffman, D. Murdiyarso, S. Kurnianto, M. Stidham, and M. Kanninen. 2011. Mangroves among the most carbon-rich forests in the tropics. Nature Geoscience 4: 293-297.

Duarte, C.M., N. Marbà, F. Gacia, J.W. Fourqurean, J. Beggins, C. Barrón, and E.T. Apostolaki. 2010. Seagrass community metabolism: Assessing the carbon sink capacity of seagrass meadows. Global Biogeochemical Cycles 24: GB4032.

Duarte, C.M., I.J. Losada, I.E. Hendriks, I. Mazarrasa, and N. Marbà. 2013. The role of coastal plant communities for climate change mitigation and adaptation. Nature Climate Change 3: 961-968.

Dubois, S., N. Savoye, A. Grémare, M. Plus, K. Charlier, A. Beltoise, and H. Blanchet. 2012. Origin and composition of sediment organic matter in a coastal semi-enclosed ecosystem: An elemental and isotopic study at the ecosystem space scale. Journal of Marine Systems 94: 64-73.

Evans, W., B. Hales, and P.G. Strutton. 2013. $\mathrm{pCO}_{2}$ distributions and air-water $\mathrm{CO}_{2}$ fluxes in the Columbia River estuary. Estuarine, Coastal and Shelf Science 117: 260-272.

Fourqurean, J.W., C.M. Duarte, H. Kennedy, N. Marbà, M. Holmer, M.A. Mateo, E.T. Apostolaki, G.A. Kendrick, et al. 2012. Seagrass ecosystems as a globally significant carbon stock. Nature Geoscience 5: 505-509.

Fujii, T., T. Fujiwara, and K. Nakayama. 2013. Fluxes of carbon dioxide in the eastern regions of Osaka Bay. JSCE Annual Journal of Coastal Engineering 69: 1111-1115 (in Japanese, English summary).

Gattuso, J.P., M. Frankignoulle, and R. Wollast. 1998. Carbon and carbonate metabolism in coastal aquatic ecosystems. Annual Review of Ecology and Systematics 29: 405-434.

Gazeau, F., A.V. Borges, C. Barrón, C.M. Duarte, N. Iversen, J.J. Middelburg, B. Delille, M.-D. Pizay, et al. 2005. Net ecosystem metabolism in a micro-tidal estuary (Randers Fjord, Denmark): Evaluation of methods. Marine Ecology Progress Series 301: 23-41.

Grimm, N.B., S.H. Faeth, N.E. Golubiewski, C.L. Redman, J. Wu, X. Bai, and J.M. Briggs. 2008. Global change and the ecology of cities. Science 319: 756-760.

Hartnett, H.E., R.G. Keil, J.I. Hedges, and A.H. Devol. 1998. Influence of oxygen exposure time on organic carbon preservation in continental margin sediments. Nature 391: 572-574.

Hendriks, I.E., T. Sintes, T. Bouma, and C.M. Duarte. 2007. Experimental assessment and modeling evaluation of the effects of seagrass (P. oceanica) on flow and particle trapping. Marine Ecology Progress Series 356: 163-173.

Hunt, C.W., J.E. Salisbury, D. Vandemark, and W. McGillis. 2011. Contrasting carbon dioxide inputs and exchange in three adjacent New England estuaries. Estuaries and Coasts 34: $68-77$.

IPCC. 2013. Carbon and other biogeochemical cycles. In: Climate Change 2013: The physical science basis. Contribution of Working Group I to the Fifth Assessment Report of the Intergovernmental Panel on Climate Change, ed. T.F. Stocker, 
D. Qin, G.K. Plattner, L.V. Alexander, S.K. Allen, N.L. Bindoff, F.-M. Bréon, J.A. Church, et al., 465-570. Cambridge: Cambridge University Press.

Jiao, N., C. Robinson, F. Azam, H. Thomas, F. Baltar, H. Dang, N.J. Hardman-Mountford, M. Johnson, et al. 2014. Mechanisms of microbial carbon sequestration in the ocean-future research directions. Biogeosciences 11: 5285-5306.

Kaushal, S.S., and K.T. Belt. 2012. The urban watershed continuum: evolving spatial and temporal dimensions. Urban Ecosystems 15: 409-435.

Kayanne, H., A. Suzuki, and H. Saito. 1995. Diurnal changes in the partial pressure of carbon dioxide in coral reef water. Science 269: 214-216.

Kayanne, H., H. Hata, S. Kudo, H. Yamano, A. Watanabe, Y. Ikeda, K. Nozaki, K. Kato, et al. 2005. Seasonal and bleaching-induced changes in coral reef metabolism and $\mathrm{CO}_{2}$ flux. Global Biogeochemical Cycles 19: GB3015.

Kennedy, H., J. Beggins, C.M. Duarte, J.W. Fourqurean, M. Holmer, N. Marbà, and J.J. Middelburg. 2010. Seagrass sediments as a global carbon sink: Isotopic constraints. Global Biogeochemical Cycles 24: GB4026.

Koho, K.A., K.G.J. Nierop, L. Moodley, J.J. Middelburg, L. Pozzato, K. Soetaert, J. van der Plicht, and G.-J. Reichart. 2013. Microbial bioavailability regulates organic matter preservation in marine sediments. Biogeosciences 10: 1131-1141.

Kone, Y.J.M., G. Abril, K.N. Kouadio, B. Delille, and A.V. Borges. 2009. Seasonal variability of carbon dioxide in the rivers and lagoons of Ivory Coast (West Africa). Estuaries and Coasts 32: 246-260.

Kouame, K.V., O.B. Yapo, V. Mambo, A. Seka, A.S. Tidou, and P. Houenou. 2009. Physicochemical characterization of the waters of the coastal rivers and the lagoonal system of Cote d'Ivoire. Journal of Applied Sciences 9: 1517-1523.

Kragh, T., and M. Søndergaard. 2009. Production and decomposition of new DOC by marine plankton communities: Carbohydrates, refractory components and nutrient limitation. Biogeochemistry 96: $177-187$

Kubo, A. 2015. Carbon cycling in Tokyo Bay. PhD Thesis, Tokyo: Tokyo University of Marine Science and Technology.

Kubo, A., M.Y. Kawai, and J. Kanda. 2015. Seasonal variations in concentration and composition of dissolved organic carbon in Tokyo Bay. Biogeosciences 12: 269-279.

Laruelle, G.G., H.H. Dürr, R. Lauerwald, J. Hartmann, C.P. Slomp, N. Goossens, and P.A.G. Regnier. 2013. Global multi-scale segmentation of continental and coastal waters from the watersheds to the continental margins. Hydrology and Earth System Sciences 17: 2029-2051.

Lønborg, C., X.A. Álvarez-Salgado, K. Davidson, and A.E. Miller. 2009. Production of bioavailable and refractory dissolved organic matter by coastal heterotrophic microbial populations. Estuaries, Coastal and Shelf Science 82: 682-688.

Macreadie, P.I., M.E. Baird, S.M. Trevathan-Tackett, A.W.D. Larkum, and P.J. Ralph. 2014. Quantifying and modelling the carbon sequestration capacity of seagrass meadows-A critical assessment. Marine Pollution Bulletin 83: 430-439.

Maher, D.T., and B.D. Eyre. 2012. Carbon budgets for three autotrophic Australian estuaries: Implications for global estimates of the coastal air-water $\mathrm{CO}_{2}$ flux. Global Biogeochemical Cycles 26: GB1032.

McIntyre, N.E., K. Knowles-Yánez, and D. Hope. 2000. Urban ecology as an interdisciplinary field: Differences in the use of "urban" between the social and natural sciences. Urban Ecosystems 4: 5-24.

McLeod, E., G.L. Chmura, S. Bouillon, R. Salm, M. Björk, C.M. Duarte, C.E. Lovelock, W.H. Schlesinger, et al. 2011. A blueprint for blue carbon: Toward an improved understanding of the role of vegetated coastal habitats in sequestering $\mathrm{CO}_{2}$. Frontiers in Ecology and the Environment 9: 552-560.
Middelburg, J.J., J. Nieuwenhuize, R.K. Lubberts, and O. van de Plassche. 1997. Organic carbon isotope systematics of coastal marshes. Estuarine, Coastal and Shelf Science 45: 681-687.

Miyajima, T., M. Hori, M. Hamaguchi, H. Shimabukuro, H. Adachi, H. Yamano, and M. Nakaoka. 2015. Geographic variability in organic carbon stock and accumulation rate in sediments of East and Southeast Asian seagrass meadows. Global Biogeochemical Cycles 29: 397-415.

Moran, M.A., W.M. Sheldon, and R.G. Zepp. 2000. Carbon loss and optical property changes during long-term photochemical and biological degradation of estuarine dissolved organic matter. Limnology and Oceanography 45: 1254-1264.

Nellemann, C., E. Corcoran, C.M. Duarte, L. Valdes, C. DeYoung, L. Fonseca, and G. Grimsditch. 2009. Blue Carbon. A Rapid Response Assessment. Birkeland: United Nations Environmental Programme, GRID-Arendal, Birkeland Trykkeri AS.

Obrador, B., and J.L. Pretus. 2012. Budgets of organic and inorganic carbon in a Mediterranean coastal lagoon dominated by submerged vegetation. Hydrobiology 699: 35-54.

Ogawa, H., Y. Amagai, I. Koike, K. Kaiser, and R. Benner. 2001. Production of refractory dissolved organic matter by bacteria. Science 292: 917-920.

Parkin, G.F., and W.F. Owen. 1986. Fundamentals of anaerobic digestion of wastewater sludges. Journal of Environmental Engineering 112: 867-920.

Pendleton, L., D.C. Donato, B.C. Murray, S. Crooks, W.A. Jenkins, S. Sifleet, C. Craft, J.W. Fourqurean, et al. 2012. Estimating global "blue carbon" emissions from conversion and degradation of vegetated coastal ecosystems. PLOS ONE 7: e43542.

Raymond, P.A., J.E. Bauer, and J.J. Cole. 2000. Atmospheric $\mathrm{CO}_{2}$ evasion, dissolved inorganic carbon production, and net heterotrophy in the York River estuary. Limnology and Oceanography 45: 1707-1717.

Raymond, P.A., J. Hartmann, R. Lauerwald, S. Sobek, C. McDonald, M. Hoover, D. Butman, R. Striegl, et al. 2013. Global carbon dioxide emissions from inland waters. Nature 503: 355-359.

Regnier, P.A.G., P. Friedlingstein, P. Ciais, F.T. Mackenzie, N. Gruber, I.A. Janssens, G.G. Laruelle, R. Lauerwald, et al. 2013. Anthropogenic perturbation of the carbon fluxes from land to ocean. Nature Geoscience 6: 597-607.

Rysgaard, S., J. Mortensen, T. Juul-Pedersen, L.L. Sørensen, K. Lennert, D.H. Søgaard, K.E. Arendt, M.E. Blicher, et al. 2012. High air-sea $\mathrm{CO}_{2}$ uptake rates in nearshore and shelf areas of Southern Greenland: Temporal and spatial variability. Marine Chemistry 128: 26-33.

Sedlak, R.I. 1991. Phosphorus and nitrogen removal from municipal wastewater: principles and practice. Boca Raton: CRC Press.

Sholkovitz, E.R. 1976. Flocculation of dissolved organic and inorganic matter during the mixing of river water and seawater. Geochimica et Cosmochimica Acta 40: 831-845.

Tanaka, Y., H. Ogawa, and T. Miyajima. 2011a. Bacterial decomposition of coral mucus as evaluated by long-term and quantitative observation. Coral Reefs 30: 443-449.

Tanaka, Y.H., H. Ogawa, and T. Miyajima. 2011b. Production and bacterial decomposition of dissolved organic matter in a fringing coral reef. Journal of Oceanography 67: 427-437.

Taylor, P.G., and A.R. Townsend. 2010. Stoichiometric control of organic carbon-nitrate relationships from soils to the sea. Nature 464: 1178-1181.

Tokoro, T., S. Hosokawa, E. Miyoshi, K. Tada, K. Watanabe, S. Montani, H. Kayanne, and T. Kuwae. 2014. Net uptake of atmospheric $\mathrm{CO}_{2}$ by coastal submerged aquatic vegetation. Global Change Biology 20: 1873-1884.

Wada, S., M.N. Aoki, A. Mikami, T. Komatsu, Y. Tsuchiya, T. Sato, H. Shinagawa, and T. Hama. 2008. Bioavailability of macroalgal 
dissolved organic matter in seawater. Marine Ecology Progress Series 370: 33-44.

Wanninkhof, R. 1992. Relationship between wind-speed and gasexchange over the ocean. Journal of Geophysical Research 97: $7373-7382$.

Watanabe, K., and T. Kuwae. 2015. How organic carbon derived from multiple sources contributes to carbon sequestration processes in a shallow coastal system? Global Change Biology 21: 2612-2623.

Watanabe, A., T. Yamamoto, K. Nadaoka, Y. Maeda, T. Miyajima, Y. Tanaka, and A.C. Blanco. 2013. Spatiotemporal variations in $\mathrm{CO}_{2}$ flux in a fringing reef simulated using a novel carbonate system dynamics model. Coral Reefs 32: 239-254.

Zonneveld, K.A.F., G.J.M. Versteegh, S. Kasten, T.I. Eglinton, K.-C. Emeis, C. Huguet, B.P. Koch, G.J. de Lange, et al. 2010. Selective preservation of organic matter in marine environments; processes and impact on the sedimentary record. Biogeosciences 7: 483-511.

\section{AUTHOR BIOGRAPHIES}

Tomohiro Kuwae $(\bowtie)$ is a Group Head at the Port and Airport Research Institute. His research interests include coastal ecology and biogeochemistry.

Address: Coastal and Estuarine Environment Research Group, Port and Airport Research Institute, 3-1-1, Nagase, Yokosuka 239-0826, Japan.

e-mail: kuwae@ipc.pari.go.jp

Jota Kanda is a Professor at the Tokyo University of Marine Science and Technology. His research interest includes marine chemistry. Address: Department of Ocean Sciences, Tokyo University of Marine Science and Technology, 4-5-7 Konan, Minato-ku, Tokyo 108-8477, Japan.

e-mail: jkanda@kaiyodai.ac.jp
Atsushi Kubo is a Post-Doctoral Researcher at the Tokyo University of Marine Science and Technology. His research interest includes marine chemistry.

Address: Department of Ocean Sciences, Tokyo University of Marine Science and Technology, 4-5-7 Konan, Minato-ku, Tokyo 108-8477, Japan.

e-mail: kuboatsushi0412@gmail.com

Fumiyuki Nakajima is an Associate Professor at the University of Tokyo. His research interest includes urban engineering.

Address: Department of Urban Engineering, The University of Tokyo, 7-3-1 Hongo, Bunkyo-ku, Tokyo 113-8656, Japan. e-mail: nakajima@env.t.u-tokyo.ac.jp

Hiroshi Ogawa is an Associate Professor at the Atmosphere and Ocean Research Institute of the University of Tokyo. His research interest includes marine chemistry.

Address: Atmosphere and Ocean Research Institute, The University of Tokyo, 5-1-5, Kashiwanoha, Kashiwa-shi, Chiba 277-8564, Japan. e-mail: hogawa@aori.u-tokyo.ac.jp

Akio Sohma is a Research Director at the Mizuho Information and Research Institute. His research interest includes ecosystem modeling. Address: Mizuho Information and Research Institute, 2-3, KandaNishikicho, Chiyoda-ku, Tokyo 101-8443, Japan. e-mail: sohmanzz@aol.com

Masahiro Suzumura is a Group Leader at the National Institute of Advanced Industrial Science and Technology. His research interest includes marine biogeochemistry.

Address: National Institute of Advanced Industrial Science and Technology, AIST Tsukuba West, 16-1 Onogawa, Tsukuba 305-8569, Japan. e-mail: m.suzumura@aist.go.jp 